KULAHA T.O. Scientific and methodical reflection of classical and contemporary vocal techniques in the context of the problem of cultural-conformity of vocal pedagogy.

The article emphasizes the general trend of contemporary non-classical singing, which is reflected in the return to the natural possibilities of the human voice. A systematic comparative description of the main features of classical and contemporary vocal techniques from the point of view of production of sound, of typical acoustic characteristics of the voice, technics, musicality and interpretation is provided. Comparisons of some positions that are advisable to take into account in the process of pedagogical interaction with teenage singers on mastering the vocal technique in contemporary styles are given. The differences between contemporary non-classical and traditional Western European vocal techniques from the standpoint of the principle of cultural-conformity are defined. This is an expanding the boundaries of the acoustic characteristics of the voice; a more clearly defined naturalness of the physiological processes that accompany non-classical singing; intuitiveness, informality and informality of the performing actions of a contemporary pop vocalist; reliance on diverse ethnic traditions; individual creative approach to interpretation and presentation of a contemporary vocal composition. Opposing positions between classical and contemporary vocal techniques (posture, air pressure, position of the larynx and tongue, sound formation, dominant muscles, sound projection, pronunciation of sounds) are determined. Link to information on the intonational and metro-rhythmic features of the musical language of contemporary pop vocal are provided. The necessity of rethinking vocal pedagogy in accordance with the results of modern research by foreign scientists and taking the obtained results in the process of working with pop vocalists of art schools is noted.

Keywords: cultural-conformity, resemantization, vocal technique, pop vocal, non-classical vocal pedagogy, non-formal education.

DOI: https://doi.org/10.31392/NZ-npu-144.2019.14

УДК 003.08:372.881.111.1]-057.875.001.85

Лазаренко Л. М.

\title{
ОСОБЛИВОСТІ КОНТРОЛЮ ЗНАНЬ, ВМІНЬ ТА НАВИЧОК ПРОФЕСІЙНО ОРІЄНТОВАНОГО ПИСЬМА АНГЛІЙСЬКОЮ МОВОЮ СТУДЕНТІВ ЕКОНОМІЧНИХ СПЕЦІАЛЬНОСТЕЙ
}

Сформовані знання, вміння та навички професійно орієнтованого письма англійською мовою у майбутніх економістів сприяють високій конкурентоспроможності циих фахівців як в Украӥні, так $i$ за кордоном. Визначено, що тільки систематичне проведення контролю будь-якого виду діяльності, зокрема письма, сприяє підвищенню успішності з дисиипліни внаслідок самокорекиії та корекиї з боку викладача. Існують численні дослідження особливостей проведення контролю саме компоненту письма, проте в даній статті автором було структуровано типи завдань відповідно до різних напрямків письма. Автором зазначено дві стадї вивчення іноземної мови у закладі вищої освіти: опанування базових знань, вмінь та навичок на рівні не ниюче B1, і також вивчення власне професійного блоку. Показано основні 3 напрямки письмових завдань для майбутніх економістів англійською мовою: заповнення економічної документації, реферування та анотування, а також написання власних наукових статей за фахом англійською мовою. Автором визначено, що написання завдань з контролю знань, вмінь та навичок професійного письма англійською мовою визначає рівень орфографічних, лексичних, граматичних та стилістичних знань, вмінь та навичок студентів. Автором підкреслено, щуо опанування знань, вмінь та навичок професійного письма студентами-економістами вимагає сформованості трьох основних компетентностей: когнітивної, метакогнітивної та стратегічної. У статті автором наведені приклади завдань для контролю кожного зі зазначених блоків, описано інструкцію до кожного з них. Показано, щуо систематичне проведення контролю письма сприяє підвищенню успішності студентів. Автор вважсає перспективним проведення подальшого емпіричного дослідження порівняння навчання та контролю знань, вмінь та навичок письма студентів нефілологічних спеціальностей (економістів) та письма студентів філологічних спеціальностей.

Ключові слова: контроль, письмо, економісти, англійська мова. 
Навчання професійної англійської мови у закладах вищої освіти $є$ надзвичайно важливим напрямком розвитку майбутніх фрахівців, зокрема економістів. Сфрормовані знання, вміння та навички письма англійською мовою обумовлюють високу конкурентоспроможність наших фахівців за кордоном, а також надають можливість міжнародної взаємодії. Поступовий контроль формування знань, вмінь та навичок протягом навчання з їх послідовною корекцією $€$ запорукою успішного навчання. 3 метою покращення якості навчання вважаємо за потрібне структурувати основні компоненти навчання професійного письма студентів-економістів, та визначити особливості письмового контролю кожного з них. У зв'язку з цим, було обрано наступну тему дослідження:

Особливості контролю знань, вмінь та навичок профресійно орієнтованого письма англійською мовою студентів економічних спеціальностей.

Мета дослідження: на підставі аналізу літератури визначити поняття “контроль професійного письма", зокрема у студентів-економістів, визначити основні компоненти контролю письма англійською мовою та описати базову типологію завдань; оцінити показники академічної успішності студентів 3 англійської мови за професійним спрямуванням (показник "письмо") при систематичному проведенні контролю профресійно орієнтованого письма.

Питання професійно спрямованого навчання іноземної (англійської) мови студентів несрілологічних спеціальностей вивчало багато українських науковців: О. Биконя [2], І. Гладка [5], К. Моруга [9], С. Семенчук [11]. Проблему навчання письма студентів-економістів саме в розрізі їх професійної діяльності, а також шляхи запровадження письмового контролю знань, вмінь та навичок письма економістів досліджували О. Березовська [1], Р. Гаращенко [4], М. Деяк [6], О. Ільїна [7], О. Карпова [8], К. Моруга [10]. Більшість авторів наголошують на важливості навчання письма англійською мовою для студентів-економістів стосовно здійснення ними їх майбутньої професійної діяльності( заповнення міжнародної звітної документації, підготовка звітів) [2; 7]. На важливості опанування письмової англійської мови для само репрезентації спікера, зокрема для підготовки наукової доповіді чи ведення письмових переговорів наголошують Ю. Семенчук [11] та О. Биконя [2]. Так само уважно вивчалось питання проведення контролю письма англійською мовою, так О.Березовська досліджувала взагалі всі фрорми письмового контролю та зазначає, що оптимальним є тестовий контроль [1]. М. Деяк [6] наголошує на важливості проведення як тестового, так і інших фрорм письмового контролю і визначає контроль профеесійного письма як "сукупність завдань, спрямованих на перевірку знань та навичок спілкування на фахові теми іноземною мовою". І. Гладка пропонує застосовувати різноманітні фооми контролю, включаючи інтерактивні методи [5]. В цілому, автори погоджуються, що навчання письмової фрахової англійської мови надзвичайно важливо для само репрезентації фрахівців, і також що проведення письмового контролю,зокрема знань, вмінь та навичок письма англійською має проводиться регулярно, із застосуванням різних методів. Авторами визначено 
так званий контроль письма( або контроль знань, вмінь та навичок письма) англійською мовою на фахові теми як сукупність завдань, спрямованих на перевірку здатності особи письмово спілкуватись на фахові теми, висловлювати власну думку, публікувати результати власних досліджень.

Проведення контролю знань, вмінь та навичок письма здійснюється згідно до стадії вивчення мови у закладі вищої освіти. Перша стадія вивчення фахової англійської мови у студентів економічних спеціальностей включає систематизацію знань, умінь та навичок в контексті графріки, орфографії та граматики англійської мови, навчання орфографії професійно спрямованої англійської мови, систематизація структурних моделей речень, властивих англійській мові взагалі та навчання структури англомовних текстів безпосередньо фрахового спрямування; та, врешті, наприкінці другої стадії вивчення англійської, - коректне використання англомовного письма для роботи за фахом, зокрема - в контексті економіки. Теоретично, випускники шкіл повинні знати іноземну мову на рівні не нижче В1, проте, на жаль, особистий досвід автора свідчить про невідповідність знань студентів першокурсників даній вимозі.

Згідно стандартів освіти та власного досвіду автора, на початковому етапі вивчення письма англійською мовою у закладі вищої освіти для контролю письма доцільно використовувати наступні вправи: аналіз слова по звуках ma літерах, протиставлення графем, диференціацію графем, словотворення, списування із різними завданнями. На більше просунутому етапі доцільно використовувати вправи на запитання відповіді, трансформацію мовного зразка, підстановку тощо. Наприкінці вивчення дисципліни, згідно отриманих результатів, доречно використовувати більш фахово орієнтовані вправи на заповнення документації, написання листів (офіційного та неофріційного) на професійну тематику, написання cmammi, реферату, анотування стаmmi ma написання наукової роботи за фахом англійською мовою. Критерієм якості вивчення певного змістовного блоку студентами є показники успішності при написання тестового контролю, як найбільш об'єктивного показника результатів. Тестовий контроль письма - така форма контролю, застосування якої дозволяє перевірити каліграфічні навички, знання орфографії, лексикології, граматики, пунктуації та стилістики, тобто всі необхідні складові показника “письмо", проте автор схиляється до виконання студентами більш творчих завдань, ніж банальне “угадування" літери відповіді у тесті.

Письмовий контроль дає можливість перевірити наступні вміння та навички письма у студентів-економістів:

1. Каліграфічні навички. Під каліграфічними навичками розуміють написання літер чи літеросполучень англійської мови. Чіткість і нормативне написання літер важливі для майбутніх економістів, зокрема при заповненні документації “від руки”, хоча здебільшого в наш час робота з документацією ведеться в електронному режимі. Проте, автор не вважає доречним знижувати оцінку за погану каліграфрію. 
2. Орфографічні знання, які ґрунтуються на основних чотирьох принципах: фонетичному (коли буква відповідає звуку), морфологічному (написання визначається правилами граматики), традиційно-історичному та ідеографічному. Заповнення студентами-економістами документації у текстових процесорах Word та подібних програмах надає їм можливість автоправки чи автокорекції, проте дані програми містять багато помилок, а, отже, необхідні знання самих спеціалістів.

3. Сформованість вмінь лексичної спрямованості передбачає засвоєння словникового запасу, який забезпечує 75-80\% лексичних одиниць при письмі. Вміння граматичної спрямованості зводяться до напрацювання розуміння та застосування основних граматичних (морфологічних та синтаксичних) явищ іноземної мови, причому лексико-граматичні вміння більшістю авторів розглядаються як єдине ціле.

При навчанні професійно спрямованої англійської мови у закладах вищої освіти, в контексті розвитку особистості майбутніх фахівців та напрацювання ними навичок спілкування на фахові теми англійською, необхідні наступні вміння та навички: навички використання доцільних лексико-граматичних конструкцій; вміння вибору незнайомих лексичних одиниць фахового та загального спрямування; вміння використовувати інтернаціональні терміни, за аналогією 3 рідною мовою; вміння диференціації та використання багатозначних слів, омонімів, антонімів та синонімів в професійному контексті англійською мовою; вміння визначення сполучуваності фахових лексичних одиниць та їх тематичної залежності, з відповідним використанням при фаховому спілкуванні; вміння та навички співвідношення граматичних категорій з функціями та відповідно використання необхідних граматичних категорій як у загальному сенсі, так i в контексті власне фрахового використання (використання пасивного стану, артиклів, за тематикою); вміння аналізувати текст та зв'язувати різні частини тексту через певний вибір лексичних одиниць та лексико-граматичних прийомів; вміння застосування необхідної структури відповідно до обраних завдань побудови тексту економічної спрямованості англійської мови (економічний звіт, аналіз тенденцій, ведення документації, виступ на конференції). Визначені навички та уміння досягаються через опанування студентами базових стратегій: когнітивних (перечитування тексту, розуміння завдань та змісту, використання різних джерел для отримання інформації та власне генерування письмових повідомлень); мета когнітивних (використання вже попередньо вивченого, постановка мети та завдань щодо виконання письмових завдань, самоконтроль), компенсаторних (використання певних шаблонів та схем укладання письмових повідомлень англійською мовою), тощо. Перевірка даного блоку здійснюється через виконання студентами письмової контрольної роботи, яка може бути упорядкована як набір тестових завдань, а також письмових завдань( починаючи з суто лексичних чи граматичних вправ i закінчуючи синтезуючими завданнями).

Проведення контролю знань, вмінь та навичок письма студентів- 
економістів англійською підпорядковується наступним принципам: принципу системності та систематичності, принципу об'єктивності, принципу структурованості, а також принципу індивідуального підходу. Розпрацьовані викладачем завдання для письмового контролю та критерії їх оцінювання несуть об'єктивний характер, проте початковий рівень опанування IM та, відповідно, зусилля студента мають також враховуватись.

Аналіз програми навчання студентів-економістів фрахової англійської мови, проведений автором, дозволив виявити основні 3 види письмових завдань при роботі з англомовними фаховими текстами: робота з економічною документацією та ведення фрахової переписки; анотування вивченого матеріалу англійською мовою; написання статей чи результатів власних економічних досліджень англійською мовою. Контроль знань, вмінь та навичок роботи 3 економічною документацією включає контроль вмінь розуміння змістовної частини документації( за допомогою вправ “Correct the offered document", "Compose your own document according to the example", "Compose the document due to the case");вмінь відповідати на запит по відсутній інформації, заповнювати документи (за допомогою вправ “Fill in the table", "Complete the scheme", "Correct the mistakes in the document", "Compose the document using the example or the offered conditions"; вмінь розуміння сутності та структури укладання економічної документації англійською мовою (що включає власне фрілологічних блок та міжпредметноінтегрований економічний блок, адже завдання базується на знання студентів з економічних дисциплін); вміння формулювання мети та завдання написання документа та вміння приводити написаний документ у відповідність з поставленими завданнями; вміння чітко та доступно передавати фахову інформацію у письмових повідомленнях (обумовлені не тільки лексико-граматичними знаннями, але i стилістичними особливостями, зв'язністю текстової частини, чіткості фрормулювання); вміння використовувати необхідний тип структури та лексичні терміни в контексті виконання завдання. Тобто, письмове повідомлення англійською мовою на фрахову тему має бути укладено: граматично, лексично та синтаксично коректно, а також повинно бути зрозумілим для читача, якість чого і перевіряється за допомогою контролю письма. Критерієм оцінювання даного компонента $€$ його відповідність стандартам граматики, коректному використанню ЛО, тощо.

Анотування англомовних текстів економічного спрямування $\epsilon$ надзвичайно важливим для студентів, які збираються продовжувати наукове дослідження, а також в контексті вивчення великої кількості англомовних економічних джерел. Контроль вмінь та навичок анотування включає в собі контроль наступних показників: вміння визначення теми повідомлення та доречності даної тематики, виділення студентом основної думки економічного тексту, вміння визначення провідних фактів та основної інформації тексту із врахуванням важливості; на підставі проведеного аналізу та синтезу прочитаного та визначення пріоритетності чи відповідності - вміння 
формулювання ключових фраз для майбутньої анотації; вміння написання кінцевої версії анотації, із дотримання всіх правил укладання академічного економічного тексту.

Контроль вмінь та навичок самостійного написання рефератів чи статей охоплює контроль вміння спланувати тему, мету та завдання, зміст та обсяг написанного ("Define the aims due to the offered task, define the plan and structure of the essay"), контроль вміння висловити власну точку зору ("According to the reviewed literature express your thoughts"), вміння структурування тексту та складання плану до тексту ("divide the text into the logical components"), вміння підводити підсумки(“Using the information, write the conclusions").

Автором особисто систематично проводиться письмовий контроль знань, вмінь та навичок письма студентів-економістів. Відмінність між результатами вступного контролю, на початку вивчення дисципліни, поточного контролю протягом вивчення дисципліни(із використанням зазначених вправ) та кінцевого контролю, показує різницю в 0,8-1,4 бали за 5-бальною шкалою оцінювання, відповідно до групи. Станом на 2018-2019 н.р., середня відмінність між результатом початкового контролю та підсумкової письмової роботи склала 0,9 балів сторону покращення. Тобто, систематичне проведення письмових контрольних робіт сприяє підвищенню вмінь самомоніторингу та самокорекції студентів, а відтак - покращенню успішності.

Висновки. Контроль знань, вмінь та навичок письма англійською мовою студентів-економістів охоплює перевірку орфографрічних, каліграфрічних, лексичних, граматичних та стилістичних знань. Зокрема, вміння укласти елементарний економічний документ англійською мовою потребує всі зазначені компоненти. Контроль знань, вмінь та навичок письма англійською мовою включає три базові блоки: знання, вміння та навички, необхідні для ведення економічної документації; для анотування чи рефрерування прочитаного, а також для написання власної наукової роботи, присвяченої певному економічному явищу. Контроль письма визначає не тільки знання студентів саме з економічної англійської мови, але рівень сформованості їх когнітивної, метакогнітивної та стратегічної компетентностей. Автором надані базові типи вправ, які можливо використовувати для контролю знань, вмінь та навичок англомовного професійного письма. Вважаємо доцільним проведення порівняльного дослідження особливостей контролю фахового письма англійською мовою у студентів-фрілологів та студентів-нефрілологічних спеціальностей.

\section{Використана література:}

1. Березовська О. В., Тригуб І. П. Особливості підготовки проведення письмового контролю знань студентів немовних спеціальностей з іноземної мови [Електронний ресурс]. dspace. 2012. Режим доступу до ресурсу: http://dspace.nuft.edu.ua/jspui/bitstream/123456789/5635/1/1\%D0\%90BerezTryhub.pdf.

2. Биконя О. П. Навчання майбутніх економістів ділових усних та писемних переговорів англійською мовою: автореф. дис. ... канд. : спец. 13.00.02 “теорія та методика навчання: германські мови” / Биконя Оксана Павлівна. Київ, 2006. 28 с.

3. Биконя О. П., Іванишина В. П. Самоконтроль рівня володіння майбутніми економістами англомовними продуктивними компетентностями. Вісник Київського національного лінгвістичного університету. Серія Педагогіка та Психологія. 2018. № 29. С. 24-31. 
4. Гаращенко Р. А., Мовчанюк Н. А. Ведення ділових усних та писемних переговорів англійською мовою-невід'ємна складова іншомовної професійної підготовки майбутніх економістів [Електронний ресурс]. Науковий вісник KHEУ. 2008. Режим доступу до ресурсу: http://ir.kneu.edu.ua/bitstream/handle/2010/11642/318-320.pdf?sequence=1.

5. Гладка І. А. Шляхи удосконалення системи педагогічного контролю в процесі вивчення англійської мови як другої іноземної. Наукові записки [Національного педагогічного університету ім. МП Драгоманова]. Серія: Педагогічні та історичні науки. 2012. № 108. С. 29-36.

6. Деяк М. Ю. Основні фактори розвитку навичок ділового письма у студентів економістів при викладанні англійської мови із залученням інтерактивних методів. Молодий вчений: науковопрактичний журнал. 2017. № 43. С. 38-42.

7. Ільїна О. М. Розвиток англомовної комунікативної компетентності студентів-економістів шляхом застосування мультимедійних засобів навчання. Молодий вчений : науково-практичний журнал. 2018. № 53. С. 89-94.

8. Карпова О. О. Дидактичні умови навчання іноземної мови майбутніх економістів засобами мультимедійних технологій. Київ : Інститут обдарованої дитини, 2015. 216 с.

9. Моруга К. О., Ільїна О. М., Лимар Л. В. Активізація пізнавальної діяльності студентів при вивченні іноземних мов у немовному вищому навчальному закладі. Наукові записки Національного педагогічного університету імені М. П. Драгоманова. Серія: Педагогічні та історичні науки. Київ : Вид-во НПУ ім. М. П. Драгоманова, 2011. Вип. 95. С. 154-159.

10. Моруга К. О., Лимар Л. В. Особливості розвитку іншомовної лінгвістичної компетенції студентів економічних спеціальностей в контексті студентоцентризму. Студентоцентризм у системі забезпечення якості освіти в економічному університеті : зб. матеріалів Всеукр. наук.-метод. конф., Київ, 2-3 березня 2016 р. Київ : КНЕУ, 2016. С. 234-235.

11. Семенчук Ю. О. Підготовка студентів-економістів до написання та презентації доповіді на наукову конференцію. Наукові записки [Національного університету Острозька академія]. Сер.: Філологічна. 2012. № 23. С. 292-293.

\section{References:}

[1] Berezovska O. V., Tryhub I. P. Osoblyvosti pidhotovky provedennia pysmovoho kontroliu znan studentiv nemovnykh spetsialnostei z inozemnoi movy [Elektronnyi resurs]. dspace. 2012. Rezhym dostupu do resursu: http://dspace.nuft.edu.ua/jspui/bitstream/123456789/5635/1/1\%D0\%90BerezTryhub.pdf.

[2] Bykonia O.P. Navchannia maibutnikh ekonomistiv dilovykh usnykh ta pysemnykh perehovoriv anhliiskoiu movoiu : avtoref. dys. ... kand. : spets. 13.00.02 "teoriia ta metodyka navchannia: hermanski movy" / Bykonia Oksana Pavlivna. Kyiv, 2006. 28 s.

[3] Bykonia O. P., Ivanyshyna V. P. Samokontrol rivnia volodinnia maibutnimy ekonomistamy anhlomovnymy produktyvnymy kompetentnostiamy. Visnyk Kyivskoho natsionalnoho linhvistychnoho universytetu. Seriia Pedahohika ta Psykholohiia. 2018. № 29. S. 24-31.

[4] Harashchenko R. A., Movchaniuk N. A. Vedennia dilovykh usnykh ta pysemnykh perehovoriv anhliiskoiu movoiu-nevidiemna skladova inshomovnoi profesiinoi pidhotovky maibutnikh ekonomistiv [Elektronnyi resurs]. Naukovyi visnyk KNEU. 2008. Rezhym dostupu do resursu: http://ir.kneu.edu.ua/bitstream/handle/2010/11642/318-320.pdf?sequence=1.

[5] Hladka I. A. Shliakhy udoskonalennia systemy pedahohichnoho kontroliu v protsesi vyvchennia anhliiskoi movy yak druhoi inozemnoi. Naukovi zapysky [Natsionalnoho pedahohichnoho universytetu im. MP Drahomanova]. Seriia: Pedahohichni ta istorychni nauky. 2012. № 108. S. 29-36.

[6] Deiak M. Yu. Osnovni faktory rozvytku navychok dilovoho pysma u studentiv ekonomistiv pry vykladanni anhliiskoi movy iz zaluchenniam interaktyvnykh metodiv. Molodyi vchenyi : naukovopraktychnyi zhurnal. 2017. № 43. S. 38-42.

[7] Ilina O. M. Rozvytok anhlomovnoi komunikatyvnoi kompetentnosti studentiv-ekonomistiv shliakhom zastosuvannia multymediinykh zasobiv navchannia. Molodyi vchenyi : naukovo-praktychnyi zhurnal. 2018. № 53. S. 89-94.

[8] Karpova O. O. Dydaktychni umovy navchannia inozemnoi movy maibutnikh ekonomistiv zasobamy multymediinykh tekhnolohii. Kyiv : Instytut obdarovanoi dytyny, 2015. $216 \mathrm{~s}$.

[9] Moruha K. O., Ilina O. M., Lymar L. V. Aktyvizatsiia piznavalnoi diialnosti studentiv pry vyvchenni inozemnykh mov u nemovnomu vyshchomu navchalnomu zakladi. Naukovi zapysky Natsionalnoho pedahohichnoho universytetu imeni M. P. Drahomanova. Seriia: Pedahohichni ta istorychni nauky. Kyiv : Vyd-vo NPU im. M. P. Drahomanova, 2011. Vyp. 95. S. 154-159. 
[10] Moruha K. O., Lymar L. V. Osoblyvosti rozvytku inshomovnoi linhvistychnoi kompetentsii studentiv ekonomichnykh spetsialnostei $\mathrm{v}$ konteksti studentotsentryzmu. Studentotsentryzm $u$ systemi zabezpechennia yakosti osvity v ekonomichnomu universyteti : zb. materialiv Vseukr. nauk.-metod. konf., Kyiv, 2-3 bereznia 2016 r. Kyiv : KNEU, 2016. S. 234-235.

[11] Semenchuk Yu. O. Pidhotovka studentiv-ekonomistiv do napysannia ta prezentatsii dopovidi na naukovu konferentsiiu. Naukovi zapysky [Natsionalnoho universytetu Ostrozka akademiia]. Ser.: Filolohichna. 2012. № 23. S. 292-293.

ЛАЗАРЕНКОЛ. Н. Особенности контроля знаний, учений и навыков профессионально ориентированного письма на английском языке у студентов экономических спеціальностей.

Сформированные знания, умения и навыки профессионально ориентированного письла на английском языке у будущих экономистов способствуют высокой конкурентоспособности специалистов как в Украине, так и за ее пределами. Показано, что только систематическое проведение контроля любого вида деятельности, в частности письма, способствует повышению успеваемости вследствие самокоррекции и коррекиии преподавателем. Существуют многочисленные исследования особенностей проведения контроля именно компонента письма, но в данной статье автором были структурированы типь заданий именно относительно разных направлений профессионального письма. Автором определены две стадии изучения иностранного языка в заведении высшего образования: освоение базовых знаний, умений и навыков на уровне не ниже BI, а также изучение именно профессионального блока. Показаны основные три направления письменных заданий для будущих экономистов на английском языке: заполнение экономической документащии, реферирование и написание аннотащий, а также написание собственных научных работ по специальности на английском языке. Автором определено, что написание заданий, которыми контролируются знания, умения и навыки профессионального письма на английском языке, определяет уровень орфографических, лексических, грамматических и стилистических знаний, умений и навыков студентов. Подчеркнуто, что освоение знаний, умений и навыков профессионального письма студентами- экономистами требует сформированости у них трех основных компетентностей: когнитивной, метакогнитивной и стратегической. В статье автором были приведены примеры заданий по контролю каждого из описанных блоков, описаны инструкции к ним. Показано, что систематическое проведения контроля письма способствует повышению успеваемости студентов. Автор считает перспективным проведение последующего эмпирического исследования сравнения обучения и результатов контроля письма у студентов нефилологических специальностей(например, экономистов и студентов филологических специальностей.

Ключевые слова. Контроль, письмо, экономисты, английский язык.

LAZARENKOL.M. Some aspects of the English professional writing control held with the students of specialization "economics".

The well-shaped skills of professional English writing in future economists provide for high competition ability of these specialists, both in Ukraine and abroad. The articles shows that only regular control of each activity, particularly of writing, leads to improved academic achievements, due to self-correction and correction by the tutor. There are multiple studies of control of the writing skills, though the article contains structural analysis of the exercises used exactly for controlling professional writing. The author defines two stages of learning English in Universities: mastering basic knowledge and skills, with the level at least equal to the B1, and the second one, learning the professional English, or the so-called English for professional purposes. The article shows three basic directions of written tasks aimed at controlling writing in future economic students: filling in the documents, writing summary and composing own scientific research in English. The author defines that the control of written English is based on checking the knowledge and skills in orthography, grammar, lexics and style, and each of these components is particularly significant. Mastering the knowledge and skills of professional writing by economic students needs for three competencies: the cognition(learning to study), metacognition(applying all possible study methods and techniques) and strategic (planning and organizing the study process) one. The author provides examples of the tasks for each of the components as well as instructions. The author supposes it would be scientifically interesting to hold a further empiric study of teaching and control of writing between the nonphilological (for example, students of economic specialization) students and those specialized in linguistics.

Keywords. Control, writing, economists, English. 